Article

\title{
Process Innovation as a Moderator Linking Sustainable Supply Chain Management with Sustainable Performance in the Manufacturing Sector of Pakistan
}

\author{
Hafiz Muhammad Shahid ${ }^{1}$, Rafay Waseem ${ }^{1}$, Humayoon Khan ${ }^{1}$, Faria Waseem ${ }^{1}$, \\ Muhammad Junaid Hasheem ${ }^{2}$ and Yangyan Shi 1,3,4,* \\ 1 Department of Economics and Management, Nanjing Agricultural University, Nanjing 210095, China; \\ hafiz.shahid123@gmail.com (H.M.S.); 2017106130@njau.edu.cn (R.W.); khanhumayoon88@yahoo.com (H.K.); \\ fariawaseem.sau@gmail.com (F.W.) \\ 2 School of Business, Jiangsu Normal University, Xuzhou 221116, China; junni.92@hotmail.com \\ 3 China Centre for Food Security Studies, Nanjing Agricultural University, Nanjing 210095, China \\ 4 Department of Management, Macquarie Business School, Macquarie University, Sydney 2121, Australia \\ * Correspondence: peter.shi@mq.edu.au
}

Received: 6 February 2020; Accepted: 3 March 2020; Published: 16 March 2020

check for updates

\begin{abstract}
Purpose: The aim of this research paper is to significantly contribute to empirical research on the impact of sustainable supply chain management (SSCM) practices on sustainable performances of firms, with the moderating effect of process innovation (PI), in the manufacturing sector in Pakistan. This paper also theorizes comprehensive SSCM practices and sustainable performance models of firms and evaluates them empirically. Two aspects of SSCM experiences have been integrated into the model: internal management and external management practices of a firm's sustainability impact assessment. Research methodology: Using the data from 297 manufacturing firms in Pakistan, this research paper analyzes the influence of sustainable supply chain management practices on sustainable performances of firms with the moderation of process innovation in the said relationship. In this study, we used partial least-squares structural equation modelling (PLS-SEM) for data analysis. Results: The findings demonstrate that both internal management and external management SSCM practices have a positive and significant impact on a firm's sustainable performance, thus supporting hypotheses $(\mathrm{H} 1-\mathrm{H} 4)$. Moreover, process innovation as a moderator has a statistically significant relationship between hypotheses $\mathrm{H} 5$ and H5c. Originality: For Pakistani firms, comprehensive performance models of SSCM practices are proposed and empirically evaluated. The results of this study help to support the hypotheses that internal and external SSCM practices are necessary for the service sector. Process innovation plays an important role if managed and implemented properly. A number of internal and external SSCM approaches and implications are recommended, along with firm size as a moderator.
\end{abstract}

Keywords: Pakistan; sustainable supply chain management; process innovation; firm's sustainable performance

\section{Introduction}

In recent years, literature has started to convey the idea that the sustainable supply chain management (SSCM) field is greatly detached from new trends in business sustainability. However, it seems to be a major step forward, but society still does not recognize it. This study should be extended. Nonetheless, based on this line of thought, it should be said that further steps should be taken in 
order to achieve a genuine understanding of sustainability by indicating that progress toward a true SSCM is an important step towards an alternative approach to a sustainable business through the internalization of more ecological thinking in business disciplines. It also argues that SSCM is well positioned to play a key role in this development. Whereas in the current SSCM literature this can be seen as a radical concept, it indicates that the SSCM could be the main contributor to creating a new and genuinely sustainable corporate strategy [1]. According to Seuring and Müller [2], SSCM can be defined as "the management of material, information and capital flows as well as cooperation among companies along the supply chain while taking goals from all three dimensions of sustainable development $[\ldots$... ] into account".

Sustainability is considered to be a fundamental principle of smart management (Gladwin et al., 1995) and an inevitable business priority [3]. Sustainability is also a global topic of increasing importance. Two-thirds of executives and managers from 113 countries, for example, report sustainability as essential to business activities [4]. Kiron says managers are not wondering why they should be sustainable, but what they should do to ensure their sustainability. This is influenced in some way by the concept of sustainability. Carter and Rogers [5] have developed a sustainability system based on the concept of triple bottom line (TBL) [6,7]. This argued that an organization must have an economically viable, environmental, and socially responsible (CSR) sustainable development.

The supply chain of manufacturing firms that are called upon to compete in a modern globalized economy will become more imprecise over the coming decades [8]; therefore the conventional way of managing the supply chain management (SCM) has proved to be ineffective in terms of cost and competitive relationships [9]. Management theories, such as neoclassical theory, suggest that an organization's main objective is to make profit. Organizations use various techniques and methods to achieve high productivity in this respect [10]. Nevertheless, previous studies found that social, environmental, and economic performance (hereby known as sustainable practices) are key to achieving greater productivity $[11,12]$. This ensures that a company will make high profits by promoting and enforcing sustainable practices [13].

The manufacturing sector in Pakistan also faces a number of problems related to SSCM. Previous research also indicates the need for more rigorous application of SSCM initiatives in Pakistan [14]. That finding is explained by the contextual setting in Pakistan. Due to the lack of sustainable policy initiatives and institutional arrangements in a developing country, the formal sector of the economy has minimal participation [15].

Pakistan, with more than 2011 million inhabitants, is the sixth most populous country in the world (Pakistan Economic Survey, 2018). About 20 million tons of solid waste is deposited annually in open fields ( $2.4 \%$ annual growth rate) with no practical solution. Solid waste management in Pakistan needs to be looked at seriously because more than five million people die each year in Pakistan from untreated waste [16]. Similarly, the manufacturing sector in Pakistan has faced many problems in its operations as a result of logistics infrastructure deficiencies $[17,18]$. Researchers therefore need to explore this burning issue.

Moreover, organizations operate in the context of low-quality products, inadequate living conditions, violations of human rights, fair wage issues that do not provide a reasonable standard of living, and, more noticeably, a very high rate of child labor. Water and environmental contamination are another threat, since most businesses mistreat their waste materials [19]. Moreover, Pakistan has a lack of awareness of CSR activities among developing countries [20]. Buckley, et al. [21] and Visser [22] therefore argued that developing countries face different issues related to sustainability that are very different from those in the developed world. Pakistan is a country that has low standards of environmental protection. Environmental degradation is a crucial issue in Pakistan, according to statistics from the government and NGOs [23]. According to the Environmental Protection Agency (EPA), Pakistan is ranked seventh on its list of the countries most impacted by global warming.

Most of the SSCM studies have dealt with issues such as social responsibility or environmental protection separately, without taking into account potential interconnections between these and other 
social responsibility aspects [24]. As competition changes from one company to the entire supply chain, market competition remains focused not only on internal management, but also on external management practices [25]. The recent review of SSCM literature by Elcio and Yew Wong [26] found that few studies have taken sustainability as a whole into consideration. The previous studies also recommend testing different performance results, for instance, to analyze the impact of SSCM practices on a firm's sustainable performance [27]. This research investigates the implementation of SSCM in Pakistani manufacturing companies for internal and external practices and analyzes their impact on sustainable performance. The current research, relating to sustainable performance outcomes activities in a new context, makes an important contribution to these studies.

Moreover, SSCM was tested in the majority of previous studies as a multidimensional variable $[28,29]$, but this study conceptualized it as a unidimensional variable. This helps to clarify the different effects of environmental management both internally and externally. Previous studies have suggested evaluating sustainable internal and external management for better results in future studies [30,31]. Moreover, until now, sustainable management has mainly been examined in a construct to assess the impact of both product and process innovation on performance [32,33]. According to the researchers' knowledge, there is no empirical study in the literature on the moderating effect of technological innovation (process innovation) between SSCM and a firm's sustainable performance. In addition, data were collected from Pakistan's manufacturing sector, a developing country with very limited SSCM research. For Asian countries and other emerging economies, a series of approaches and consequences of SSCM practices is recommended [30,34]. Secondly, SSCM practices were divided into internal and external management. The relationship between internal and external management practices and a firm's sustainable performance was not studied simultaneously in previous literature. It is recommended to test the said relationship in future studies [30]. Moreover, in the manufacturing sector of Pakistan, the contribution of the Pakistani government in implementing sustainability has been very limited. According to Sajjad and Eweje [35], “there is an urgent need for government to develop a national sustainability policy through consultative process involving businesses, trade unions, chamber of commerce, NGOs, academia, and other stakeholder groups." Therefore, awareness of the importance of sustainability must be raised at community and corporate levels.

\section{Literature Review}

\section{SSCM Practices}

Over the last decade, academic and corporate interests have evolved in SSCM practices [36,37]. SSCM refers to management of the supply chain that determines all members of the supply chain meet social, environmental, and economic requirements [37-39]. Given the history of sustainability, it was not until the end of the 1980s that sustainability became significant in the supply chain. Most SSCM work dealt separately with issues like environment protection or social responsibility, without considering the possible links between these aspects and social responsibility [24]. In the transition of business from a single company to the entire supply chain, competition in the market remains the focus not only for internal management but also for external management practices [25]. In this context, companies should not only concentrate on their own quality assurance work, but they should also seek to broaden management to customers and suppliers in order to manage the whole supply network [40].

Internal practices include those that may be planned, developed, and implemented within the organization, whereas external practices rely on the cooperation of external parties such as customers and suppliers [41]. The SSCM definition shows that companies are enhancing their internal procedures through social practices (e.g., improving supplier processes) and environmental practices (e.g., the production process). Internal Environmental Management (IEM) integrates SSCM into an organization's strategy and shows its contribution by means of a top management vision, participation of middle management, and the development of cross-functional teams across all organizational members [42]. IEM is the basis for the entire SSCM process of constructive businesses. Eco-Design is proactive in 
coping with environmental degradation and maintaining compliance in the early stages of the product lifecycle with emissions control. It also helps in saving the possible costs to be incurred in the future for controlling the damages [43]. From idea generation to designing products that use fewer materials, low energy, and reduce harmful emissions, these can have significant economic and environmental effects on their results $[44,45]$.

In recent years, social sustainability has also become increasingly attractive through increased awareness of health, equity, education, security, and bonded labor and corporate ethical practices [46]. Social sustainability practices in the supply chain have mainly focused on health and safety and legislative concerns rather than on ethical and cultural issues. The social sustainability of the supply chain relies on different firms, and many stakeholders, including suppliers and manufacturers, are also part of the supply chain. Social sustainability can make it possible for an organization to achieve a high degree of benefit; otherwise, poor social responsibility management could adversely affect it [46].

SSCM faces significant challenges because each individual in the supply chain can have an impact on the performance of other members of the supply chain. The supplier is the most significant external member to influence the performance of the supply chain [47], and environmental and social crises of the supplier have a profound impact on the performance and reputation of the core company. It is particularly important to monitor and evaluate suppliers. Organizations have gradually realized that the company's development strategy will stretch from traditional corporate governance to the management of supply chain partners [48]. The task of environmental cooperation research has focused primarily on its antecedents and its impact on its results. Collaborative planning, estimation, and refilling processes help firms quickly overcome financial challenges that lead to successful sustainability initiatives in the supply chain [30].

According to Damanpour and Evan [49], technological innovation can be defined as "the implementation of an idea for a new product or a new service or the introduction of new elements in an organization's production process or service operation." Nevertheless, Singh, et al. [50] reported that material technologies have been applied in organizations to technical problems. For example, an organization may create standardized tasks and resources to execute the application or build an application. Moreover, they also stated that the technological path is considered to be a possible direction for a technological tool that contributes to the development of a technological paradigm.

Technological innovation (process innovation) has become a focal point of top management in different firms in the modern business world. It is argued that those companies with modern technology are successful in the turbulent markets for products and services [51]. A company with unique resources and capabilities in strategic management literature may achieve a sustainable competitive position in a volatile market, especially in the context of a resource-based view (RBV), and outperform their closest competitors and industry rivals $[52,53]$. Process innovation helps businesses in developing a number of new products and services that are essential to their high income and performance [54]. The company's target of high profit can particularly be achieved by process innovation in emerging markets [55]. Process innovation allows a company to become a leader in a specific sector in an unpredictable world and to take advantage of business gains easily.

Therefore, with no or less process innovation, companies can minimize their sales growth effectively [56]. In addition to being feasible in one specific industry [57], technological innovation enhances its output in various industries including manufacturing and services by implementing process innovation [58]. Process innovation has a more significant impact on company performance and success compared to non-technological innovations [59]. Process innovation is an important driver that contributes significantly to company performance.

The present study is based on RBVs of firms $[53,60,61]$ aimed at examining the relationship between SSCM practices (e.g., internal management and external management) and a firm's sustainable performance. The role of resources and capabilities in describing continuing performance differences among companies is highlighted by the RBV [62]. Resources of an organization are tangible and intangible assets [63], whereas a group of assets may accomplish a certain function or operation [64]. 
According to the RBV, scarce and valuable resources provide businesses with productivity that cannot be duplicated and provide immaterial resources for the growth of businesses [65].

This research seeks in a number of ways to narrow the difference in current literature. First, by using RBV and examining the relationship between company's resources and capabilities to the performance, the study contributes to SSCM literature. Based on electricity shortages, political instability, and macroeconomic and bureaucratic corruption, companies in developing countries face a challenging business environment [66]. In such adverse situations, organizations are striving to survive, which lead to a greater focus on business performance.

Nonetheless, in line with RBV, businesses need to be more cautious, take greater risks, and implement technology to remain competitive and thrive on the market. Strong relationships with suppliers also improve the efficiency of a firm [67]. Organizations are building their trust and relying increasingly on corporate networks to compete with them.

\section{Research Framework and Hypotheses}

This paper discusses internal and external management practices and sustainable performance analyses of firms to assess sustainable management practices of organizations. Below are the research framework and hypotheses development.

\subsection{Internal Environmental Management Practices and a Firm's Sustainable Performance}

Resource-based view combines internal environmental practices and the performance of the firm. Studies by Zhu and Sarkis [68], Zhu, et al. [69], and Beske and Seuring [70] have shown that sustainable policies should be introduced (i.e., environmental management systems, waste management, product design and quality management) that lead to better performance of the firm. Social sustainability relies on both internal and external aspects. The positive impact on both sides of environmental management practices can be expected. For instance, clean production lines will reduce pollution and change the working conditions of workers and the environment and boost the social reputation of the firm.

However, strategic research literature underlines corporate environmental responsibility, integrates it into the economic strategy, and therefore reduces the utilization of resources and improves stakeholder relationships and brand image, which increase revenues. Studies by Zhu and Sarkis [68], Zhu, Sarkis and Geng [69], and Rao and Holt [71] advocated the positive impact of environmental management practices on economic performance. At the firm level, it would increase production efficiency and decrease use of energy by using environmentally friendly processes and materials, and ultimately reduce cost of production. We thus assume the following:

Hypothesis 1 (H1). Internal environmental management practices have a positive and significant effect on the sustainable performance of firms.

\subsection{Internal Social Responsible Management and Firm Sustainable Performance}

The role and training of staff in CSR management contribute positively to improving the environment [72]. Kolk [73] argues that more participation in CSR management, for example internal employees and external communities, will improve public knowledge and company performance on environmental protection. Researchers anticipate that the sustainable performance of the company guided by corporate social responsibility policies is strengthened by the results of Florida [72] and Marshall, et al. [74]. There are two parts of CSR management practices (internal employees and external communities). Internal practice (for the safety of workers, working conditions) and external practice (for communities and clients) can boost the performance of the enterprise. Walker and Jones [75] proposed that businesses improve employee work conditions and their safety, which can boost employee satisfaction, prevent accidents, and eventually improve efficiency and reduce losses. We expect organizations to manage internal socially responsible management in order to improve the efficiency of production. Thus, we assume the following: 
Hypothesis 2 (H2). Internal socially responsible management practices have a positive and significant effect on the sustainable performance of firms.

External Supplier Management and Firm Sustainable Performance

There is a disparity between supply chain theory and sustainable practice for external management [76]. When businesses grow, the supplier becomes the largest external member that affects the output of the supply chain [47]. Many organizations are beginning to create a supplier assessment system or partnership development in order to strengthen environmental protection and social responsibility values within the supply chain.

\subsection{Supplier Monitor and Assessment and a Firm's Sustainable Performance}

Researchers have used the RBV and transaction cost theory (TCT) to examine the said relationship. Transaction costs are a crucial factor for selecting transaction modes between companies and suppliers, according to TCT. The cost of transactions covers direct relationship management costs and future decision-making opportunities costs. Many manufacturers may be dishonest in carrying out environmental and social responsibility or in violation of the law. Organizations need to use expensive monitoring and evaluation systems to track suppliers in order to reduce the likelihood of such actions. Monitoring practice focuses on evaluating the performance of the actual supplier and monitors potential unreasonable activities of the supplier.

In addition, suppliers are required to report about the safety of chemical storage products or guarantee their services in accordance with the SA8000 standard labor rights, etc. Monitoring and evaluation of the supply chain is important with regard to social and environmental factors. According to Gimenez and Sierra [77], a supplier's monitoring and assessment has a positive impact on the firm's sustainable performance. We therefore expect firms to use evaluation and tracking methods to reduce supplier risk to boost the firm's sustainable performance. We thus assume the following:

Hypothesis 3 (H3). Supplier monitor and assessment has a positive and significant effect on the sustainable performance of firms.

\subsection{Supplier Collaboration and a Firm's Sustainable Performance}

Collaboration between suppliers can include various levels of operations, such as strategy, information, etc. [78]. Working together with the suppliers emphasizes the shared interest rather than a short-term activity [79]. According to RBV, valuable and scarce resources and capacity provide competitiveness to businesses that cannot be duplicated and provide intangible resources for business development [65]. Carter and Rogers [36] stated that intangible resources can promote environmental performance, such as mutual learning and understanding of nature and the customer. SSCM will benefit from a good provider relationship. Pagell and Gobeli [80] have underlined that partnerships can build mutual trust and become more likely to participate in sustainable social issues. Gimenez and Sierra [77] pointed to a positive impact on the sustainable performance of the company in a supplier's collaboration and assessment. Monitoring suppliers and collaboration between suppliers can support companies in achieving greater productivity and lowering waste emissions. The reduced consumption of resources may decrease the cost of production. We therefore assume the following:

Hypothesis 4 (H4). Supplier collaboration has a positive and significant effect on the sustainable performance of firms.

\subsection{Technological Innovation as a Moderator Between SSCM Practices and a Firm's Sustainable Performance}

There have been studies in various developing and emerging economies that investigate SSCM's relationship to firm performance, so this is not a new trend [81]. Some studies show mixed SSCM results and firm results: positive, negative, and unrelated [82-84]. Such dubious findings establish a 
study void that necessitates further research to produce satisfactory results. The relationship of SSCM and a firm's sustainable performance actually has two opposing theoretical foundations. Some argue that there is a negative relationship, as it is assumed that SSCM will increase costs if manufacturing firms make charitable contributions, develop environmental protection procedures, and support social development programs. On the other hand, others suggest that there is a strong partnership as SSCM increases employee satisfaction and trust in businesses [20]. Social activities can also strengthen relationships with government authorities, investors, and bankers, leading to easy access to capital for companies [85].

Research on the relationship between SSCM practices and a firm's sustainable performance and technological innovation (process innovation) as moderator, in particular SSCM research in developing countries, is still in its infancy. Existing studies have focused mainly on the organizational environment, the social environment, and the management of supply chain members [86]. In addition, this study specifically examines, unlike previous research, how technological innovation influences sustainable performance and how it links to a positive effect on sustainable performance. This is an important research question because it helps companies understand how technology innovation is helping to achieve superior performance [54].

The RBV theoretical framework provides clear analysis of innovation and its linkage to performance [87-90]. In order to explain heterogeneity in strategy and performance, RBV uses its internal characteristics. Only firms with special capabilities and resources with special characteristics will obtain competitive advantages according to the main principle of RBV and, thus, achieve superior achievements [54].

Due to its causal ambiguity, technological innovation is one of the main sources of competitive advantage [91-93]. In particular, process innovation can perform any relevant technical functions or volume within a company, including the development of new products and processes and the operation of efficient installations [94]. The statistical evidence that technological innovation is a major driver for sustainable performance has been presented recently by empirical research $[33,95]$. The empirical research supports technological innovation's strategic potential to produce more sustainable results.

Process innovation is aimed at shortened delivery lead time or lower operational costs in technological innovations [96] and improves the production and distribution of the commodity by the firm [97]. Therefore, process innovation has an internal focus on efficiency [98], which enables companies to follow cost management strategies [99]. This paper therefore proposes a research model as shown in Figure 1 to examine the role of technological innovation (process innovation) as a moderator between SSCM and a firm's sustainable performance. We therefore assume the following:

Hypothesis 5a (H5a). Technological innovation (process innovation) has a moderating effect on the relationship between internal environmental management practices and a firm's sustainable performance.

Hypothesis $\mathbf{5 b} \mathbf{b} \mathbf{H} \mathbf{b})$. Technological innovation (process innovation) has a moderating effect on the relationship between internal socially responsible management practices and a firm's sustainable performance.

Hypothesis 5c (H5c). Technological innovation (process innovation) has a moderating effect on the relationship between supplier monitor and assessment and a firm's sustainable performance.

Hypothesis $\mathbf{5 d}$ (H5d). Technological innovation (process innovation) has a moderating effect on the relationship between supplier's collaboration and a firm's sustainable performance.

Keeping in view the above discussion and gaps in the literature, we proposed the theoretical framework as shown in Figure 1. 


\section{Independent Variables}

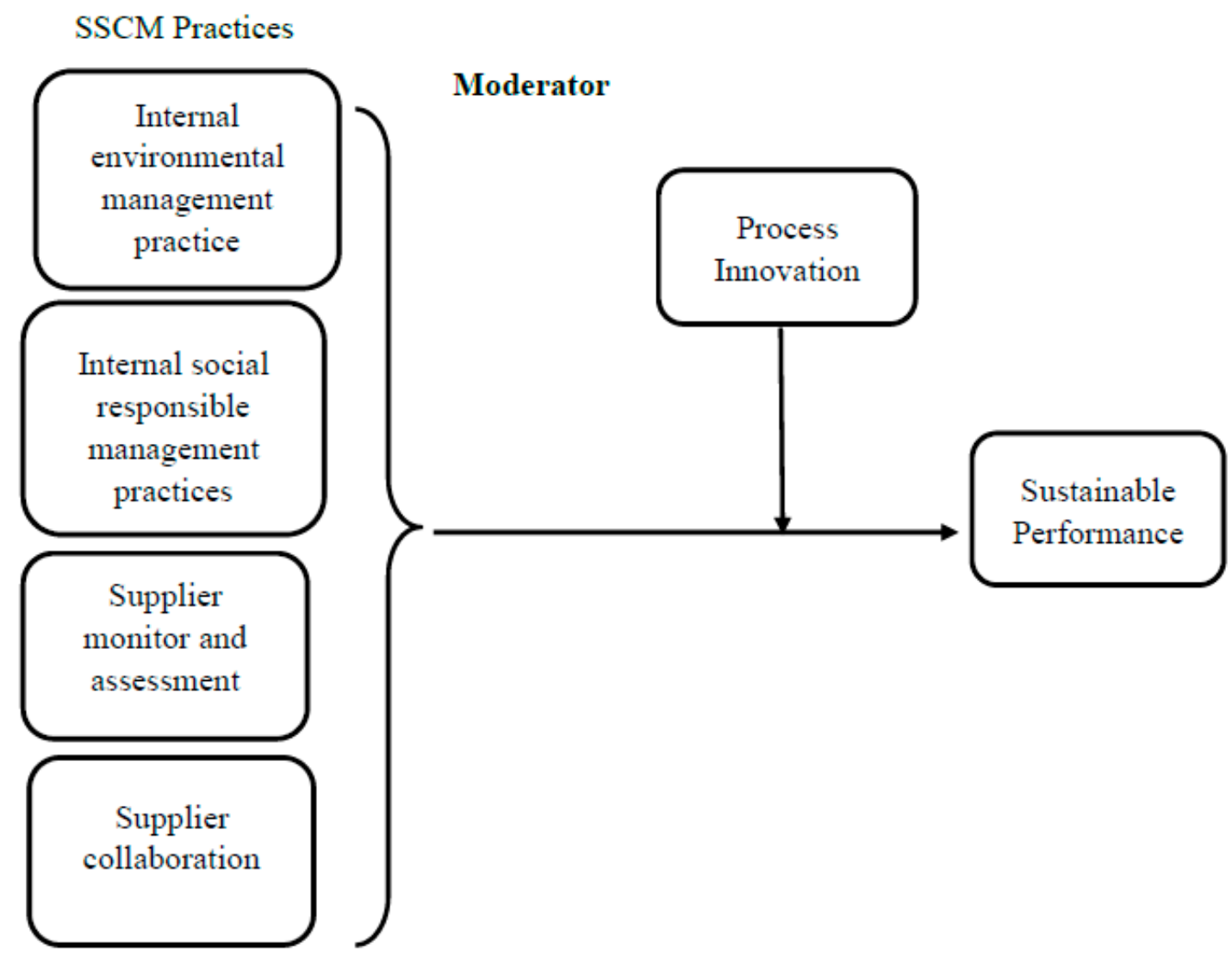

Figure 1. Research model. Sustainable supply chain management.

The model shows the proposed research framework that forms the basis of this study. This focuses on the firm's performance, which is determined by SSCM practices (e.g., internal environmental management practices, internal socially responsible management, supplier monitor and assessment, and supplier collaboration). In this context, process innovation acts as a moderator in the relationship between SSCM practices and a firm's sustainable performance. In this research, RBV was used as an underpinning theory. Furthermore, the relationship between variables under research is explained by RBV and TCT theory. Keeping the above discussion in mind, the following hypotheses are developed:

Hypothesis 1 (H1). Internal environmental management practices have a positive and significant effect on a firm's sustainable performance.

Hypothesis 2 (H2). Internal socially responsible management practices have a positive and significant effect on a firm's sustainable performance.

Hypothesis 3 (H3). Supplier monitor and assessment have a positive and significant effect on a firm's sustainable performance.

Hypothesis 4 (H4). Supplier collaboration has a positive and significant effect on a firm's sustainable performance.

Hypothesis 5a (H5a). Technological innovation (process innovation) has a moderating effect on the relationship between internal environmental management practices and a firm's sustainable performance. 
Hypothesis $\mathbf{5 b} \mathbf{( H 5 b ) . ~ T e c h n o l o g i c a l ~ i n n o v a t i o n ~ ( p r o c e s s ~ i n n o v a t i o n ) ~ h a s ~ a ~ m o d e r a t i n g ~ e f f e c t ~ o n ~ t h e ~ r e l a t i o n s h i p ~}$ between internal socially responsible management practices and a firm's sustainable performance.

Hypothesis 5c (H5c). Technological innovation (process innovation) has a moderating effect on the relationship between supplier monitor and assessment and a firm's sustainable performance.

Hypothesis 5d (H5d). Technological innovation (process innovation) has a moderating effect on the relationship between supplier's collaboration and a firm's sustainable performance.

\section{Methodology}

The survey respondents were executives, chain supervisors, and directors of manufacturing companies from Faisalabad, Lahore, and Sialkot, the three largest industrial cities in the province of Punjab, Pakistan. The study was cross-sectional in nature. In this study, a questionnaire was used to determine the relationship between SSCM practices, process innovation, and sustainable performance in the manufacturing sector of Pakistan. For data collection, the researchers used a self-administered approach. According to Sekaran and Bougie [100], questionnaires distributed personally may lead to a higher response rate. This research was carried out by analyzing the organizational perspective of the above variables.

The five- and seven-point Likert style scale was used to calculate all questions concerning SSCM practices, process innovation, and a firm's sustainable performance. A total of 400 questionnaires were distributed in the manufacturing sector (i.e., leather products, textiles, chemicals, pharmaceuticals, and sports) to workers in the three major cities of Punjab, Pakistan. A total of 305 completed questionnaires were returned from the participants, and almost three months of the data collection process was completed. However, out of the 305 questionnaires returned, 22 questionnaires were considered unusable due to incomplete information and were discarded. The remaining 283 questionnaires accounted for a response rate of $75.46 \%$, which was sufficient for further analysis, as suggested by Sekaran and Bougie [100], where a response of $30 \%$ would be sufficient for further analysis.

The research instrument used for this survey was designed in accordance with the literature. The questionnaire included multiple items for each of the constructs used. Measurement scales have been derived from the literature. Internal environmental management is a higher-order reflective/formative variable, including eco-design products, sustainable packaging, and environmental protection management. Product eco-design with a seven (7)-item scale was adopted from Carter, et al. [101], $\mathrm{Zhu}$, Sarkis and Geng [69], and Yu, et al. [102]. Sustainable packaging products with a six (6)-item scale was adopted from Dang and Chu [103] and Zailani, Jeyaraman, Vengadasan and Premkumar [43]. Environmental protection management with an eight (8)item scale was adopted from Zhu, Sarkis and Geng [69] and Zsidisin and Hendrick [104]. Internal socially responsible management is also a higher-order reflective/formative variable, including human rights, philanthropy, and safety. Human rights with a six (6)-item scale was adopted from Carter and Jennings [24] and Emmelhainz and Adams [105]. Philanthropy with a four (4)-item scale was adopted from Carter and Jennings [24]. Safety with a three (3)-item scale was adopted from Carter and Jennings [24] and Zhu, Sarkis and Geng [69].

Supplier monitor and assessment scale was measured with a nine (9)-item scale. Similar metrics are proposed and validated in the literature by Krause, et al. [106] and Carter, Kale and Grimm [101]. Supplier collaboration was measured by an eight (8)-item scale. Similar metrics are proposed and validated in the literature by Krause, Scannell and Calantone [106], Bowen, Cousins, Lamming and Farukt [76], and Claudia, et al. [107]. To develop a specific measurement scale for process innovation capabilities, this study adapted previously validated scales by Tuominen and Hyvönen [108] and Camisón and Villar López [109]. The variable was measured with an eleven (11)-item scale. A firm's sustainable performance is a higher-order reflective/formative variable, including environmental, social, and economic dimensions. Economic performance was measured by a six (6)-item scale, adopted from 
De Giovanni et al. and Green et al. Environmental performance was measured by an eight (8)-item scale, adopted from Daily, et al. [110] and Zhu, et al. [111]. Social performance was measured by a six (6)-item scale, adopted from Kassinis and Soteriou [112] and Gimenez, et al. [113].

In this analysis, we used the partial least-squares (PLS) approach to structural equation modelling (SEM). This approach is used extensively in business analysis in areas like marketing, management, information systems, and communications [114] and has a strong capacity to handle complex models [115]. In this research, Smart PLS software (3.0 version) was used to evaluate the measurement model and structural model. According to Hair, et al. [116], PLS-SEM is preferred over covariance-based SEM software such as AMOS since PLS-SEM is specifically designed for predictive purposes.

\section{Data Analysis and Discussion}

\subsection{Measurement Model}

To assess the measurement model, the current study followed the recommendations of several prominent researchers in the PLS analysis area [117-119], in order to determine the (i) individual item reliability, (ii) internal consistency reliability, (iii) convergent validity, (iv) discriminant validity at the construct level, and (v) discriminant validity at the item level. For each construct, the 'individual item reliability' was assessed by examining outer loadings of items for each measure [117,120-122]. The items between 0.40 and 0.70 can be retained, but the remaining need to be deleted [117]. 'Internal consistency reliability' is the extent to which all the items of a given scale measure the same concept $[123,124]$. For the assessment of 'internal consistency reliability' of a scale, the 'Cronbach's alpha and composite reliability coefficients' appear to be the most commonly used estimators in the organizational research settings [125]. Therefore, to ascertain the internal consistency reliability of the adapted measures for this study, the researchers also utilized 'Cronbach's alpha' and the 'composite reliability coefficient'. However, the literature suggests that the use of composite reliability is more appropriate than Cronbach's alpha.

This research examines that out of eighty (80) items, seven (7) items have been deleted due to poor loading, and the remaining 73 items have been retained. The remaining 73 items were kept in this research model, which carried loadings between 0.604 and 0.907 respectively. In this analysis, composite reliability (CR) of all variables ranged from 0.847 to 0.913 , suggesting that all variables had a satisfactory level of internal consistency, as recommended by $[120,126]$. Results showed that for all variables, the average value was between 0.508 and 0.783 , consistent with Chin [127] rule of thumb, which specifies that the threshold value should be above 0.50 . Table 1 shows constructs outer loaders, composite reliability, average variance extracted and variance inflation factor values.

Furthermore, the assessment of the measurement model stage one is also represented in Figure 2 which is reflective in nature.

Discriminant validity can be defined as the degree to which a particular variable differs from other variables in the model [121]. The variable-level discriminant validity was tested after [128] proposing a method called the Heterotrait-Monotrait (HTMT) Correlation Ratio to determine the discriminant validity. 
Table 1. Loadings, Composite Reliability, and Average Variance Extracted.

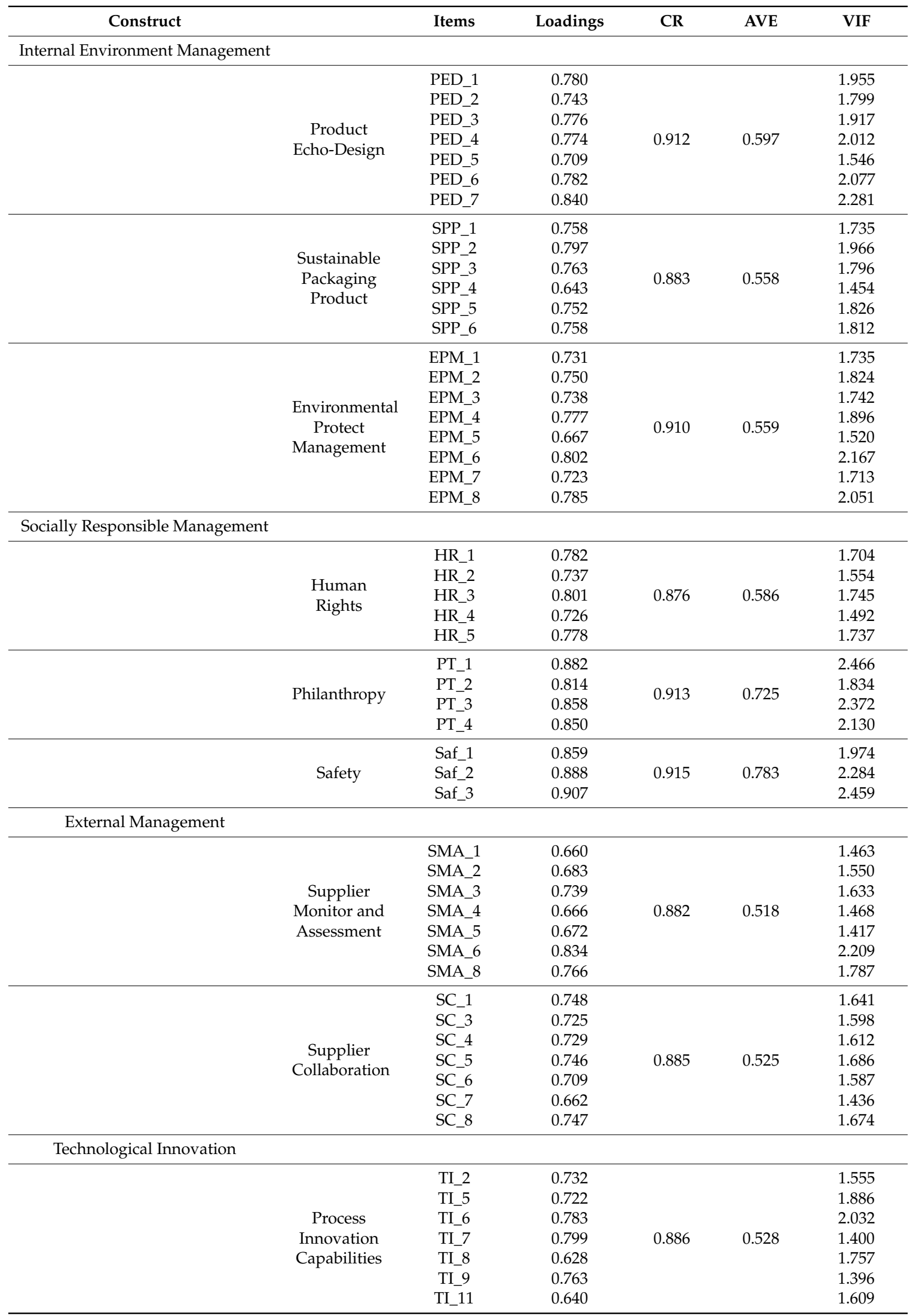


Table 1. Cont.

\begin{tabular}{|c|c|c|c|c|c|c|}
\hline Construct & & Items & Loadings & CR & AVE & VIF \\
\hline \multicolumn{7}{|c|}{ Sustainable Performance } \\
\hline & \multirow{5}{*}{$\begin{array}{l}\text { Economic } \\
\text { Performance }\end{array}$} & EcP_1 & 0.753 & \multirow{5}{*}{0.847} & \multirow{5}{*}{0.526} & 1.472 \\
\hline & & EcP_3 & 0.713 & & & 1.476 \\
\hline & & $\mathrm{EcP}_{4} 4$ & 0.717 & & & 1.507 \\
\hline & & EcP_5 & 0.701 & & & 1.609 \\
\hline & & EcP_6 & 0.740 & & & 1.707 \\
\hline & \multirow{7}{*}{$\begin{array}{l}\text { Environmental } \\
\text { Performance }\end{array}$} & EnP_1 & 0.708 & \multirow{7}{*}{0.878} & \multirow{7}{*}{0.508} & 1.501 \\
\hline & & EnP_2 & 0.695 & & & 1.490 \\
\hline & & EnP_3 & 0.751 & & & 1.848 \\
\hline & & EnP_4 & 0.735 & & & 1.639 \\
\hline & & EnP_5 & 0.684 & & & 1.572 \\
\hline & & EnP_6 & 0.604 & & & 1.337 \\
\hline & & EnP_7 & 0.798 & & & 2.029 \\
\hline & \multirow{6}{*}{$\begin{array}{c}\text { Social } \\
\text { Performance }\end{array}$} & SP_1 & 0.739 & \multirow{6}{*}{0.864} & \multirow{6}{*}{0.516} & 1.542 \\
\hline & & SP_2 & 0.630 & & & 1.346 \\
\hline & & SP_3 & 0.751 & & & 1.622 \\
\hline & & SP_4 & 0.735 & & & 1.664 \\
\hline & & SP_5 & 0.764 & & & 1.779 \\
\hline & & SP_6 & 0.683 & & & 1.470 \\
\hline
\end{tabular}

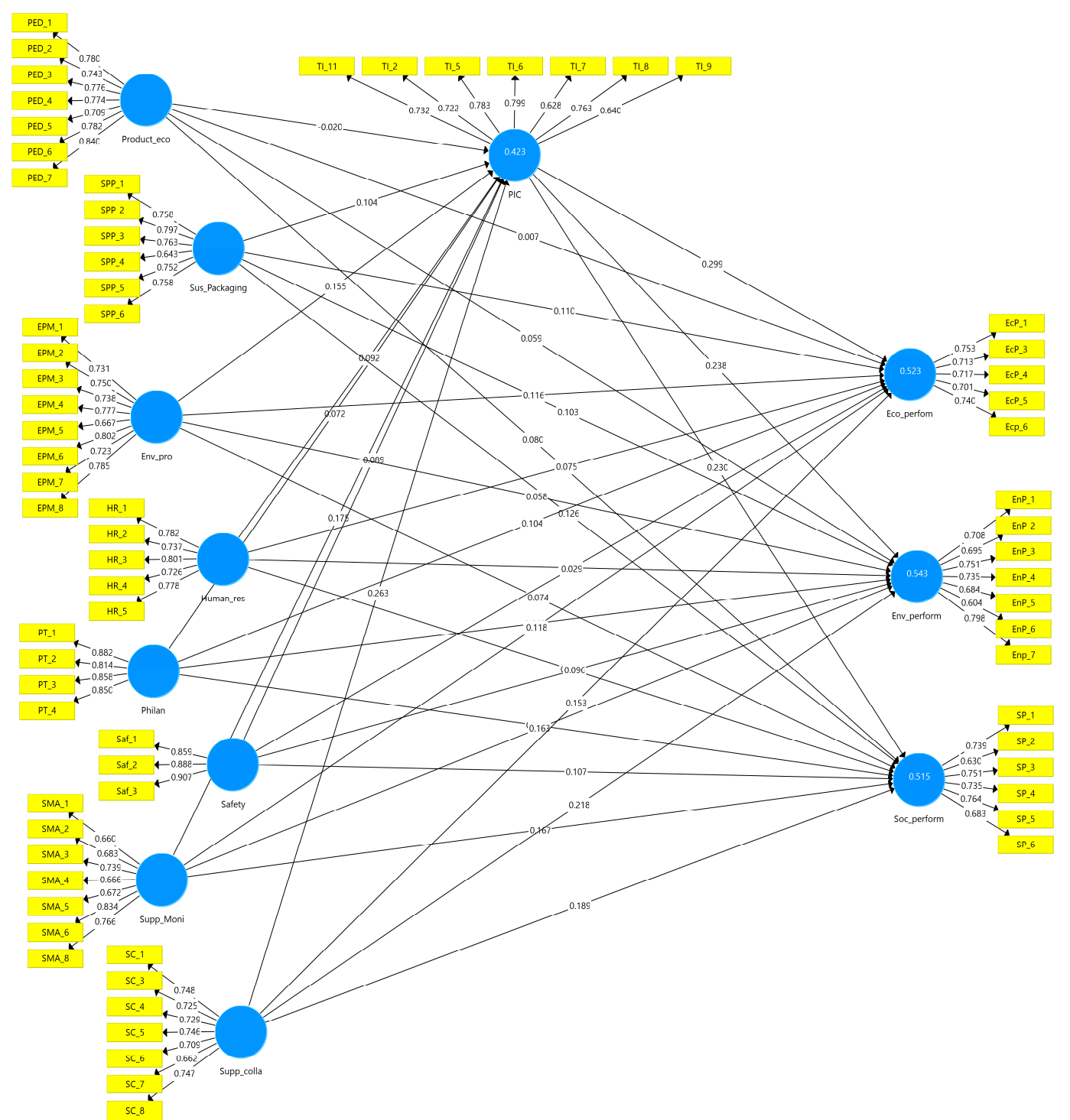

Figure 2. Assessment of measurement model stage one. 
All correlation values between variables were smaller than the suggested threshold value of 0.85, as indicated by Henseler, Ringle and Sarstedt [128]. It is therefore summarized that all research variables were different from each other and obtained the discriminant validity on the basis of the HTMT method. The measurement model of the present study was, therefore, confirmed to be valid and reliable. Table 2 shows the HTMT values of all the latent constructs.

Table 2. Results of discriminant validity (HTMT).

\begin{tabular}{|c|c|c|c|c|c|c|c|c|c|c|c|c|}
\hline & EcP & EnP & EPM & HR & PIC & Phil & PED & Safety & SP & SMA & SC & SP \\
\hline \multicolumn{13}{|c|}{$\mathrm{EcP}$} \\
\hline EnP & 0.836 & & & & & & & & & & & \\
\hline EPM & 0.612 & 0.562 & & & & & & & & & & \\
\hline HR & 0.553 & 0.536 & 0.489 & & & & & & & & & \\
\hline TI & 0.753 & 0.705 & 0.553 & 0.484 & & & & & & & & \\
\hline Phil & 0.520 & 0.467 & 0.470 & 0.375 & 0.424 & & & & & & & \\
\hline PED & 0.461 & 0.490 & 0.458 & 0.494 & 0.393 & 0.363 & & & & & & \\
\hline Safety & 0.429 & 0.474 & 0.432 & 0.416 & 0.413 & 0.344 & 0.390 & & & & & \\
\hline $\mathrm{SP}$ & 0.786 & 0.834 & 0.567 & 0.497 & 0.692 & 0.453 & 0.507 & 0.481 & & & & \\
\hline SMA & 0.606 & 0.621 & 0.489 & 0.457 & 0.553 & 0.462 & 0.407 & 0.389 & 0.620 & & & \\
\hline SC & 0.617 & 0.652 & 0.466 & 0.455 & 0.584 & 0.298 & 0.435 & 0.298 & 0.622 & 0.479 & & \\
\hline SP & 0.595 & 0.580 & 0.553 & 0.502 & 0.502 & 0.473 & 0.555 & 0.390 & 0.595 & 0.464 & 0.431 & \\
\hline
\end{tabular}

Establishment of the Higher-Order Constructs

The present study consists of a hierarchal component modeling framework that integrates two Higher-Order Components (HOCs) such as internal environmental management, social responsibility management, and sustainable business efficiency, which are measured by their Lower-Order Components (LOCs). It should be noted that this study has a reflective/formational HOC, indicating a relationship between HOCs and LOCs (reflecting/formative). The second stage of the measurement model is measured by weights, VIF, $t$-values, and $p$-values. Before starting stage two of the measurement model, we performed a redundancy analysis of the reflective/formative scale by a single global item. The minimum threshold value of the redundancy was 0.07 , as suggested by [116]. Therefore, it is important to investigate whether HOC can be conceptually explained before entering the path model test by their corresponding relationship with LOCs. Table 3 shows the values of convergent validity, weights, VIF, t-values, $p$-values of HOC of formative constructs.

Table 3. Measurement model of second-level constructs (formative).

\begin{tabular}{ccccccc}
\hline & Items & Convergent Validity & Weights & VIF & t-Values & $p$-Values \\
\hline Internal & PED & & 0.289 & 1.380 & 3.510 & 0.000 \\
Environment & SPP & 0.717 & 0.440 & 1.491 & 5.691 & 0.000 \\
Management & EPM & & 0.512 & 2.356 & 6.578 & 0.000 \\
\hline Socially & HR & & 0.500 & 1.215 & 5.672 & 0.000 \\
Responsible & Phil & 0.790 & 0.459 & 1.167 & 5.768 & 0.000 \\
Management & Safety & & 0.385 & 1.193 & 4.709 & 0.000 \\
\hline \multirow{2}{*}{ Sustainable } & EcP & & 0.398 & 2.006 & 6.884 & 0.000 \\
Performance & EnP & 0.799 & 0.382 & 2.356 & 5.323 & 0.000 \\
& SP & & 0.355 & 2.124 & 5.472 & 0.000 \\
\hline
\end{tabular}

Furthermore, the assessment of the measurement model stage two is also represented in Figure 3 which is reflective/formative in nature. 


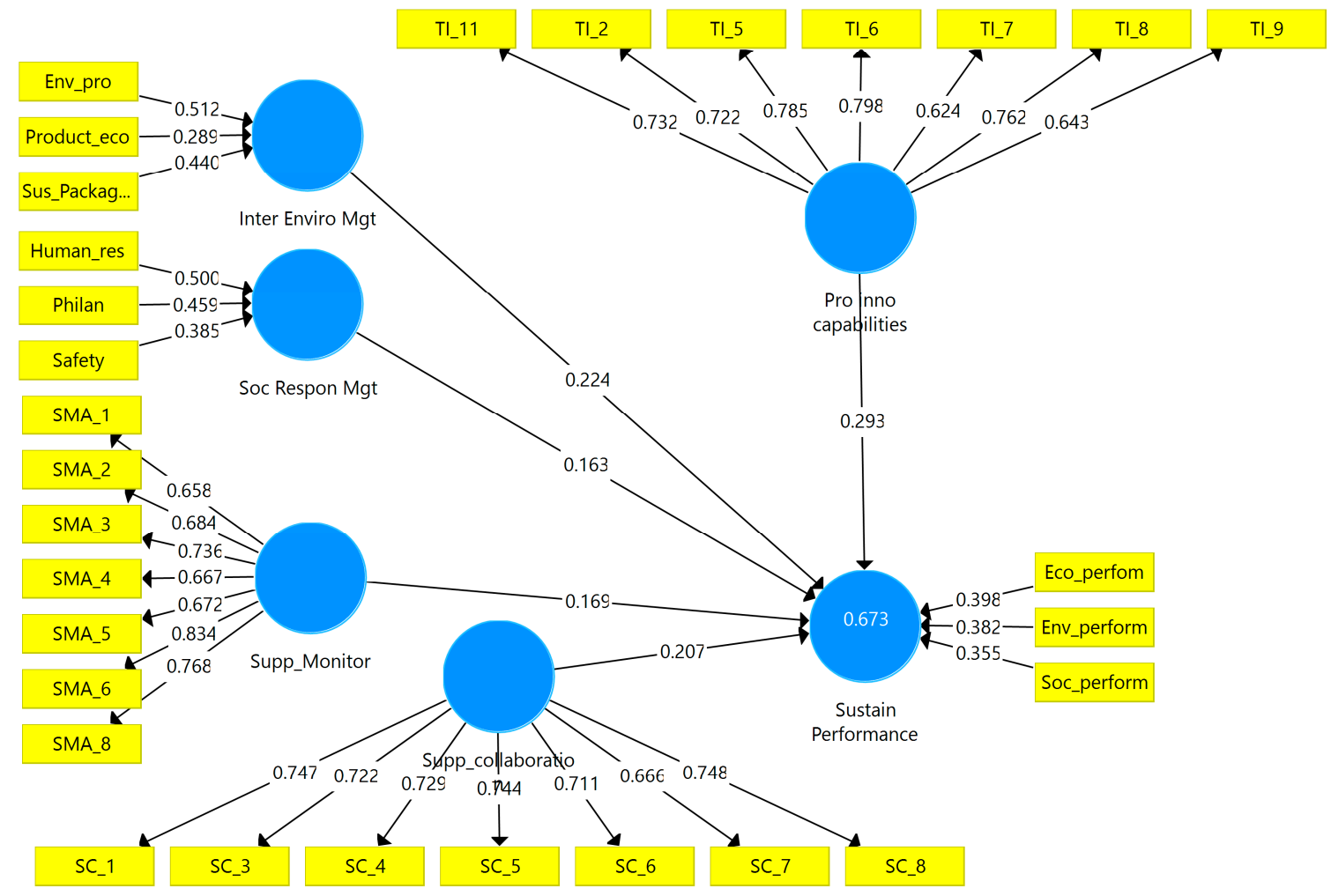

Figure 3. Assessment of the measurement model stage two.

After the measurement model was evaluated, this study then tested the structural model where the regular bootstrapping technique (with 5000 bootstrap samples and 297 cases) was used to determine the significance of the path coefficients. This was done on the basis of the relevant literature $[116,117,119,120]$. Table 4 and Figure 4 provides full estimates of the structural model. Table 4 also summarizes the overall results of the hypotheses tests.

Table 4. Assessment of structural model direct relationships and mediating variables.

\begin{tabular}{|c|c|c|c|c|c|}
\hline $\mathbf{H}$ & $\begin{array}{l}\text { Direct Paths } \\
\text { Relationship }\end{array}$ & $\begin{array}{c}\text { Path } \\
\text { Coefficient }(\beta)\end{array}$ & Standard Error & T Statistics & Decision/Hypothesis \\
\hline H1 & $\begin{array}{l}\text { Internal Environment } \\
\text { Management -> } \\
\text { Sustainable Performance }\end{array}$ & 0.217 & 0.074 & 2.953 & Supported \\
\hline $\mathrm{H} 2$ & $\begin{array}{l}\text { Socially Responsible } \\
\text { Management -> } \\
\text { Sustainable Performance }\end{array}$ & 0.154 & 0.057 & 2.687 & Supported \\
\hline H3 & $\begin{array}{l}\text { Supplier Monitor and } \\
\text { Assessment -> } \\
\text { Sustainable Performance }\end{array}$ & 0.143 & 0.052 & 2.722 & Supported \\
\hline $\mathrm{H} 4$ & $\begin{array}{l}\text { Supplier collaboration -> } \\
\text { Sustainable Performance }\end{array}$ & 0.157 & 0.051 & 3.108 & Supported \\
\hline
\end{tabular}




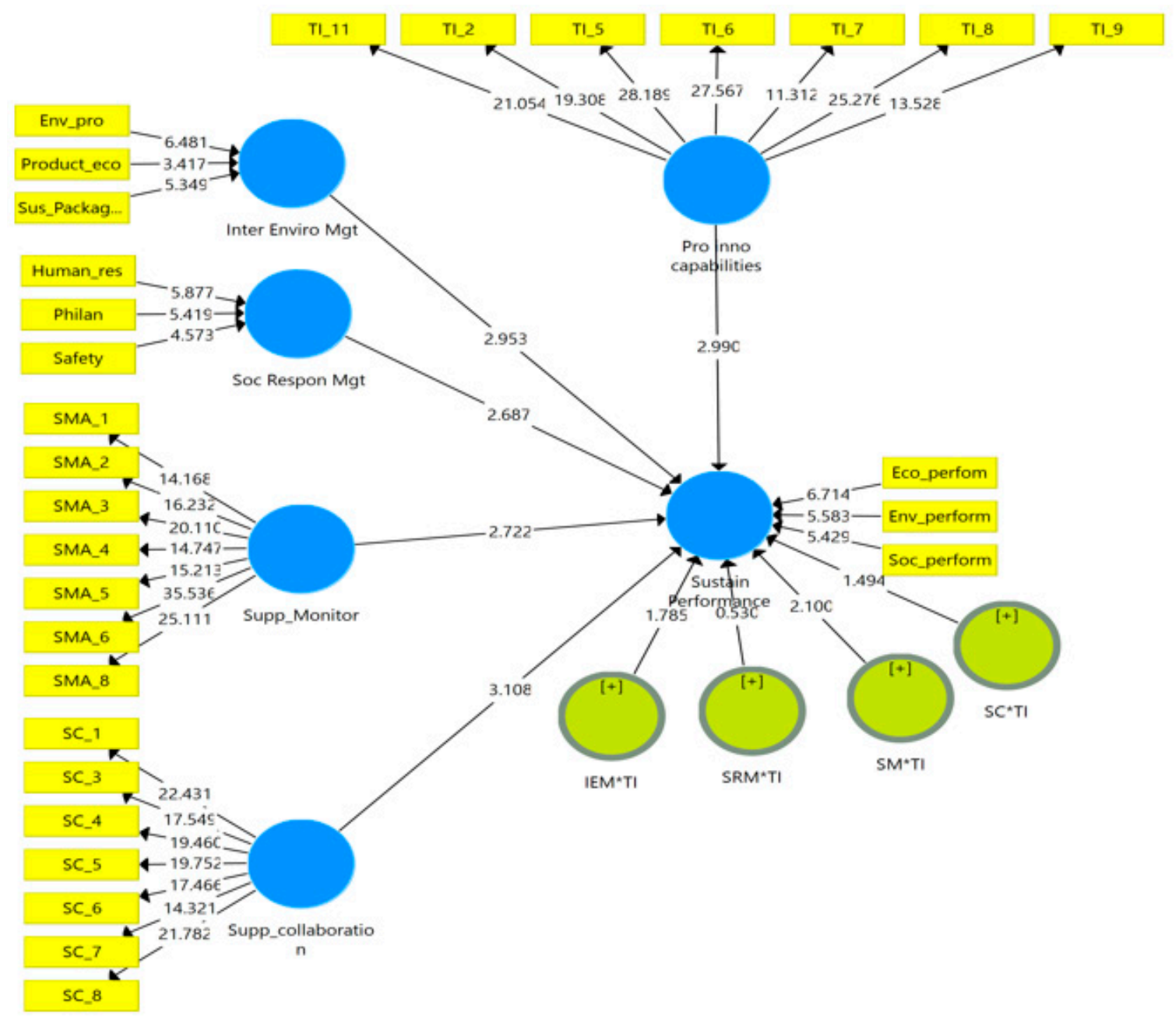

Figure 4. Assessment of structural model.

The results (see in Figure 4 and Table 4) indicate that all the four direct hypothesized relationships were significant, thus supporting the hypotheses (H1-H4). In brief, a positive and significant relationship included (i) internal environment management and a firm's sustainable performance ( $\beta=0.217$, $\mathrm{t}$-value $=2.953$ ) supporting H1; (ii) social responsible management and a firm's sustainable performance $(\beta=0.154$, $t$-value $=2.687$ ) confirming H2; (iii) supplier monitor and assessment and a firm's sustainable performance $(\beta=0.143$; $\mathrm{t}$-value $=2.722)$ that gives support for H3; (iv) supplier collaboration and a firm's sustainable performance $(\beta=0.157$, t-value $=3.108)$ confirming H4 respectively. The above discussion relating to the results of the structural path model is also shown in Figure 4 which showed the values of hypothesized relationships and their $\mathrm{t}$-values.

\subsection{Moderation Test}

Like the direct hypotheses, this study also tested the moderating effect of process innovation on the relationship between exogenous and endogenous constructs. Figure 6 shows the PLS-SEM bootstrapping moderating effect results of process innovation on the said relationship. The results showed that technological innovation (process innovation) had a moderating effect on the relationship between internal environment management and a firm's sustainable performance, as the interaction effect of IEM ${ }^{*}$ TI was significant $(\beta=0.126, p<0.039)$, confirming that H5a was supported. Likewise, technological innovation (process innovation) cannot create any moderating effect on the relationship between socially responsible management and a firm's sustainable performance. The structural model results indicate insignificant interaction effects of SRM ${ }^{*} \mathrm{TI}$ on the said relationship $(\beta=-0.036$, 
$p<0.297)$, thus rejecting hypothesis H5b. Precisely, the results of the study showed that technological innovation (process innovation) had a moderating effect on the relationship between supplier monitor and assessment and a firm's sustainable performance, as the interaction effect of SMA*TI was significant ( $\beta=0.129, p<0.019)$, thus supporting hypothesis H5c. Finally, the relationship between supplier collaboration and a firm's sustainable performance was not moderated by the technological innovation (process innovation), as the interaction effect of SC*TI was statistically not significant $(\beta=-0.073$, $p<0.068$ ), thus rejecting hypothesis H5d. Table 5 showed the results of the structural model path coefficient.

Table 5. Structural model path coefficient assessment with moderators.

\begin{tabular}{|c|c|c|c|c|c|}
\hline $\mathbf{H}$ & $\begin{array}{l}\text { Paths Relationship } \\
\text { with Moderation }\end{array}$ & $\begin{array}{c}\text { Path } \\
\text { Coefficient }(\beta)\end{array}$ & Standard Error & T Statistics & Decision/Hypothesis \\
\hline $\mathrm{H} 5 \mathrm{a}$ & $\begin{array}{c}\text { IEM }{ }^{*} \text { PI }->\text { Sustainable } \\
\text { Performance }\end{array}$ & 0.126 & 0.071 & 1.785 & Supported \\
\hline $\mathrm{H} 5 \mathrm{~b}$ & $\begin{array}{c}\text { SRM }{ }^{*} \text { PI }->\text { Sustainable } \\
\text { Performance }\end{array}$ & -0.036 & 0.067 & 0.530 & Not Supported \\
\hline $\mathrm{H} 5 \mathrm{c}$ & $\begin{array}{l}\text { SMA*PI -> Sustainable } \\
\text { Performance }\end{array}$ & 0.129 & 0.062 & 2.100 & Supported \\
\hline $\mathrm{H} 5 \mathrm{~d}$ & $\begin{array}{l}\text { SC*PI -> Sustainable } \\
\text { Performance }\end{array}$ & -0.073 & 0.049 & 1.494 & Not Supported \\
\hline
\end{tabular}

Interaction Plot

The definition of moderation suggests that a variable that modifies the directions and/or strengthen the relationship between a predictor or independent and a criterion or dependent variable is called moderator (Baron \& Kenny, 1986). In fact, in the moderating effect, the slope of the predictor is no longer constant; rather, it depends linearly on the moderator level [129]. Moreover, Hayes [127] stated that visual representation of the interaction effect is an excellent way to understand the moderator. Thus, this study adapted a Microsoft excel format suggested by Dawson [130] visual present the moderating effect in which line tagged high PI, which indicates the presence of process innovation, has a steeper gradient as against low PI (absence of process innovation). From the excel template, the two significant moderating effects of process innovation are illustrated as shown in Figures 5 and 6.

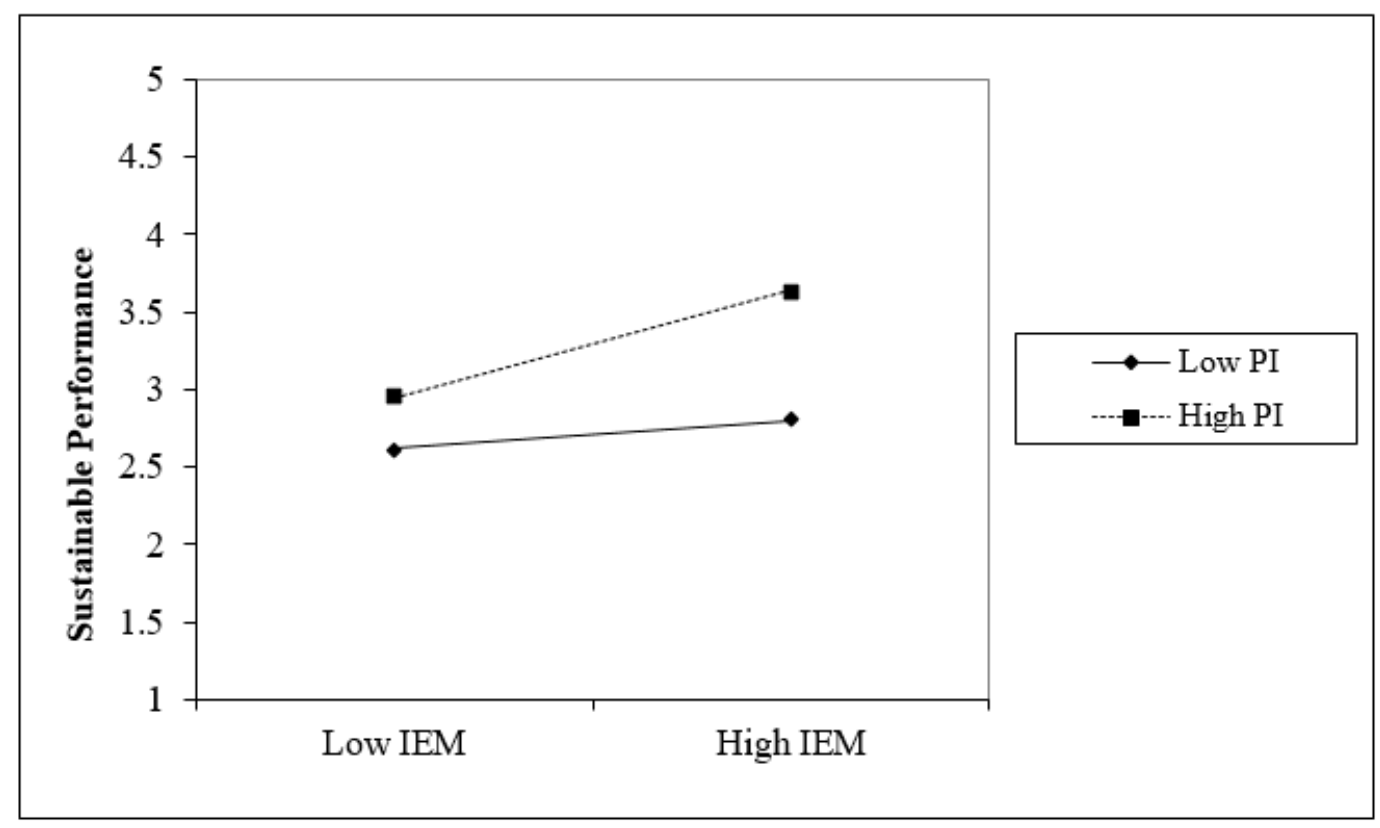

Figure 5. Interaction effect of internal environment management, process innovation and sustainable performance. 


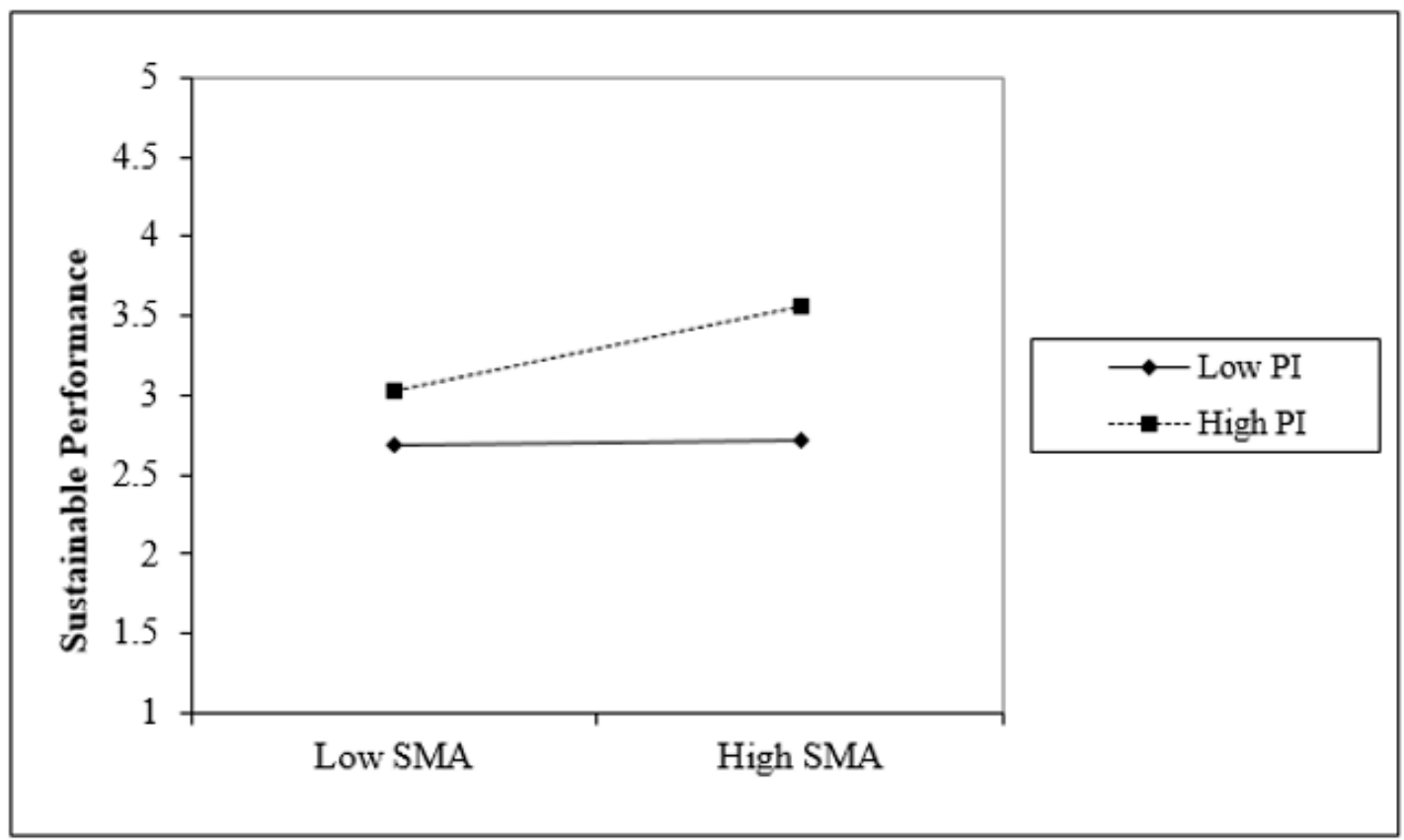

Figure 6. Interaction effect of supplier monitor and assessment, process innovation and sustainable performance.

\subsection{Assessment of the Variance Explained in the Endogenous Latent Variables}

The study also used the coefficient of determination ( $R^{2}$ value) as one of the parameters for evaluating the structural model in PLS-SEM [119]. R-squared is a measure of the proportion of the variance of an endogenous construct that is explained by its predictor design (Hair et al., 2013). For endogenous variables, the acceptable levels of $R^{2}$ are $0.19,0.33$, and 0.67 and could be defined as low, moderate, or significant [127]. The minimum acceptable $\mathrm{R}^{2}$ value for scholars, as recommended by Falk and Miller [131], is 0.10. As shown in Table 6, this research model explained $67.3 \%$ of the total variance in sustainable performance. This implies that internal environment management, socially responsible management, supplier monitor and assessment, and supplier collaboration (exogenous latent constructs) collectively explained $67.3 \%$ of the variance in endogenous variable (sustainable performance).

Table 6. Variance Explained in the Endogenous Latent Constructs.

\begin{tabular}{cc}
\hline Latent Constructs & Variance Explained $\left(\mathbf{R}^{2}\right)$ \\
\hline Sustainable Performance & $67.3 \%$ \\
\hline
\end{tabular}

\subsection{Assessment of Effect Size $\left(f^{2}\right)$}

To evaluate the $\mathrm{R}^{2}$ value of the endogenous variable, this study also examined the effect size. This shows the effect of a particular exogenous latent variable on the endogenous latent variable by means of R-squared change [127]. Therefore, effect size can be calculated as [130]: $R^{2}$ included and $R^{2}$ excluded represent $R^{2}$ value of the exogenous latent variable when the selected exogenous variable is included or excluded from the model. Cohen [130] suggested that $\mathrm{f}^{2}$ values of $0.02,0.15$, and 0.35 are weak, moderate, and strong effects, respectively. Table 7 shows the calculation and the result of the effect size of each of latent variable. Table 7 provides a calculation of the proportion of the sustainable performance (endogenous construct) that is explained by the predictor constructs. 
Table 7. Effect sizes of the coefficient of determination.

\begin{tabular}{ccc}
\hline Latent Constructs & Effect Sizes $\left(\mathbf{f}^{2}\right)$ & Degree of Effect \\
\hline In case of Sustainable & & \\
Performance: & & \\
Internal environment management & 0.074 & Small \\
Socially responsible management & 0.042 & Small \\
Supplier monitor and assessment & 0.057 & Small \\
Supplier collaboration & 0.088 & Small \\
Technological innovation & 0.154 & Medium \\
\hline
\end{tabular}

\section{Conclusions and Managerial Implications}

The aim of this paper was to explore a number of environmental and CSR practices and their effect on company sustainability. SSCM practices should help ensure a firm's performance on the basis of RBV and TCT. Data from 297 manufacturing firms in Pakistan were analyzed, with SSCM practices covering the four dimensions: IEM, SRM, supplier monitor and assessment, and supplier's collaboration, which have different impacts on firm's sustainable performance. Sustainable performance can be improved by companies working closely with suppliers to promote corporate success. This paper shows how SSCM activities impact the sustainable performances of firms. SSCM practices play important roles in fostering a consistent performance of the company, which enhances the competitive value of the business.

This research paper has important managerial implications for Pakistani firms, especially manufacturing firms and possibly for other developing countries. First of all, organizations need to consider and be more proactive in their application of these strategies and the potential positive effect that SSCM practices can have on sustainable outcomes. Environmental management should be strengthened by companies, such as recycling product design, recyclable packaging, reduction in emissions, and ISO14001 implementation. Organizations should also improve SRM, like the rights safety of workers, safe and healthy working conditions for employees, improved career advancement opportunities for employees, public benefits, good social welfare, and less or no accidents during working hours. Organizations may improve their performance through these practices.

Second, businesses should know that improving the sustainable performance of the firm is a process in which intangible assets are accumulated and are not so concerned. Unless companies disregard environmental and social responsibility that sacrifice their corporate image and reputation, they cannot pursue their economic interests. In the long run, businesses should strengthen the management of SRM to promote sustainable development and the natural environment.

Eventually, businesses should be mindful of the implementation of internal and external SSCM policies. Current SSCM practices that directly affect the performance of the company and improve the performance of the manufacturing firms can, in effect, bring economic benefits to the corporate sector. Success of SSCM practices is acute in the context of strategic supplier collaboration.

Research Limitations and Future Research

For future research, this study has certain constraints that can be strengthened. Firstly, we analyzed the four dimensions of SSCM practices concerning their direct effect on a firm's sustainable performance. In order to further improve the results, future studies of the theoretical model will add new variables to SSCM practice process. For instance, SSCM practices have different impacts on the output of the various industries (i.e., automotive and food industries). Secondly, the SSCM was split into two main dimensions: internal management practices and external management practices. Future studies should be conducted to test these SSCM practices with each dimension of a firm's sustainable performance in different sectors. Lastly, the collected data only reflected the current position of the firms in the questionnaire. The survey had not taken into account the different business measures to adopt the SSCM practices and the inherent bias of the respondents in terms of SSCM. Future studies 
may investigate dynamic changes at various SSCM stages by using time series data or panel data. Reducing the subjective factors and biases of the participants and conducting a broader sample survey will be a future piece of work. This study used process innovation as a moderator. Future studies may incorporate other moderating variables, such as firm size, to test the relationship between SSCM practices and a firm's sustainable performance in the service sector of developing economies.

Author Contributions: Conceptualization, R.W. and Y.S.; methodology, R.W.; software, H.M.S.; validation, R.W. and Y.S.; formal analysis, F.W.; investigation, R.W.; data curation, M.J.H.; writing—original draft preparation, H.K. and R.W.; writing-review and editing, R.W.; supervision, Y.S. All authors have read and agreed to the published version of the manuscript.

Funding: The authors acknowledge the sponsorship of "A project funded by the Priority Academic Program Development of Jiangsu Higher Education Institutions (PAPD)", Fundamental research funds for the central universities of China (Project No. SKCX2018002), and the APC was funded by Nanjing Agricultural University China.

Acknowledgments: The Authors are grateful to the School of Economics and Management, Nanjing Agricultural University, China for its financial and moral support. Moreover, the authors are also thankful to the reviewers for their positive suggestions that help to improve the content of this study.

Conflicts of Interest: The authors are well informed about the objectives of this current study, and they have provided consent and declared that they have no competing interest.

\section{References}

1. Nieuwenhuis, P.; Touboulic, A.; Matthews, L. Is Sustainable Supply Chain Management Sustainable? In Sustainable Development Goals and Sustainable Supply Chains in the Post-Global Economy; Springer: Berlin/Heidelberg, Germany, 2019; pp. 13-30.

2. Seuring, S.; Müller, M. From a literature review to a conceptual framework for sustainable supply chain management. J. Clean. Prod. 2008, 16, 1699-1710. [CrossRef]

3. Porter, M.E.; Kramer, M.R. The link between competitive advantage and corporate social responsibility. Harv. Bus. Rev. 2006, 84, 78-92.

4. Kiron, D.; Kruschwitz, N.; Haanaes, K.; von Streng Velken, I. Sustainability nears a tipping point. Mit Sloan Manag. Rev. 2012, 53, 69-74. [CrossRef]

5. Eklington, J. Cannibals with Forks: The Triple Bottom Line of the 21st Century; New Society Publishers: Stoney Creek, CT, USA, 1998.

6. Elkington, J. Enter the triple bottom line. In The Triple Bottom Line: Does It All Add Up? Henriques, A., Richardson, J., Eds.; Earth Scan: London, UK, 2004.

7. Fera, M.; Fruggiero, F.; Lambiase, A.; Macchiaroli, R.; Miranda, S. The role of uncertainty in supply chains under dynamic modeling. Int. J. Ind. Eng. Comput. 2017, 8, 119-140. [CrossRef]

8. Nagel, M.H. Environmental supply-chain management versus green procurement in the scope of a business and leadership perspective. In Proceedings of the IEEE International Symposium on Electronics and the Environment, San Francisco, CA, USA, 10 May 2000; pp. 219-224.

9. Khan, S.Z.; Yang, Q.; Waheed, A. Investment in intangible resources and capabilities spurs sustainable competitive advantage and firm performance. Corp. Soc. Responsib. Environ. Manag. 2019, 26, 285-295. [CrossRef]

10. Almeida, M.F.L.d.; Melo, M.A.C.d. Sociotechnical regimes, technological innovation and corporate sustainability: From principles to action. Technol. Anal. Strateg. Manag. 2017, 29, 395-413. [CrossRef]

11. Grewatsch, S.; Kleindienst, I. When does it pay to be good? Moderators and mediators in the corporate sustainability-corporate financial performance relationship: A critical review. J. Bus. Ethics 2017, 145, 383-416. [CrossRef]

12. Eccles, R.G.; Ioannou, I.; Serafeim, G. The impact of corporate sustainability on organizational processes and performance. Manag. Sci. 2014, 60, 2835-2857. [CrossRef]

13. Tipu, S.A.A.; Fantazy, K. Exploring the relationships of strategic entrepreneurship and social capital to sustainable supply chain management and organizational performance. Int. J. Product. Perform. Manag. 2018, 67, 2046-2070. [CrossRef] 
14. Rathore, P.; Kota, S.; Chakrabarti, A. Sustainability through remanufacturing in India: A case study on mobile handsets. J. Clean. Prod. 2011, 19, 1709-1722. [CrossRef]

15. Zahidi, F. Solid Waste Management in Pakistan; ALJAZEERA News: Qatar, Doha, 2016.

16. Puertas, R.; Martí, L.; García, L. Logistics performance and export competitiveness: European experience. Empirica 2014, 41, 467-480. [CrossRef]

17. Arkader, R.; Ferreira, C.F. Category management initiatives from the retailer perspective: A study in the Brazilian grocery retail industry. J. Purch. Supply Manag. 2004, 10, 41-51. [CrossRef]

18. Ehsan, S.; Nazir, M.; Nurunnabi, M.; Raza Khan, Q.; Tahir, S.; Ahmed, I. A Multimethod Approach to Assess and Measure Corporate Social Responsibility Disclosure and Practices in a Developing Economy. Sustainability 2018, 10, 2955. [CrossRef]

19. Javeed, S.; Lefen, L. An Analysis of Corporate Social Responsibility and Firm Performance with Moderating Effects of CEO Power and Ownership Structure: A Case Study of the Manufacturing Sector of Pakistan. Sustainability 2019, 11, 248. [CrossRef]

20. Buckley, P.J.; Doh, J.P.; Benischke, M.H. Towards a renaissance in international business research? Big questions, grand challenges, and the future of IB scholarship. J. Int. Bus. Stud. 2017, 48, 1045-1064.

21. Visser, W. Corporate social responsibility in developing countries. In The Oxford Handbook of Corporate Social Responsibility; Oxford University Press: Oxford, UK, 2008.

22. Waqas, M.; Dong, Q.-1.; Ahmad, N.; Zhu, Y.; Nadeem, M. Critical Barriers to Implementation of Reverse Logistics in the Manufacturing Industry: A Case Study of a Developing Country. Sustainability 2018, 10, 4202. [CrossRef]

23. Carter, C.R.; Jennings, M.M. Logistics social responsibility: An integrative framework. J. Bus. Logist. 2002, 23, 145-180. [CrossRef]

24. Sila, I.; Ebrahimpour, M.; Birkholz, C. Quality in supply chains: An empirical analysis. Supply Chain Manag. Int. J. 2006, 11, 491-502. [CrossRef]

25. Elcio, M.T.; Yew Wong, C. Towards a theory of multi-tier sustainable supply chains: A systematic literature review. Supply Chain Manag. Int. J. 2014, 19, 643-663.

26. Croom, S.; Vidal, N.; Spetic, W.; Marshall, D.; McCarthy, L. Impact of social sustainability orientation and supply chain practices on operational performance. Int. J. Oper. Prod. Manag. 2018, 38, 2344-2366. [CrossRef]

27. Feng, M.; Yu, W.; Wang, X.; Wong, C.Y.; Xu, M.; Xiao, Z. Green supply chain management and financial performance: The mediating roles of operational and environmental performance. Bus. Strategy Environ. 2018, 27, 811-824. [CrossRef]

28. Hong, J.; Zhang, Y.; Ding, M. Sustainable supply chain management practices, supply chain dynamic capabilities, and enterprise performance. J. Clean. Prod. 2018, 172, 3508-3519. [CrossRef]

29. Wang, J.; Dai, J. Sustainable supply chain management practices and performance. Ind. Manag. Data Syst. 2018, 118, 2-21. [CrossRef]

30. Khan, S.A.R.; Qianli, D. Impact of green supply chain management practices on firms' performance: An empirical study from the perspective of Pakistan. Environ. Sci. Pollut. Res. 2017, 24, 16829-16844. [CrossRef] [PubMed]

31. Calantone, R.J.; Cavusgil, S.T.; Zhao, Y. Learning orientation, firm innovation capability, and firm performance. Ind. Mark. Manag. 2002, 31, 515-524. [CrossRef]

32. Tsai, K.-H. The impact of technological capability on firm performance in Taiwan's electronics industry. J. High Technol. Manag. Res. 2004, 15, 183-195. [CrossRef]

33. Foo, P.-Y.; Lee, V.-H.; Tan, G.W.-H.; Ooi, K.-B. A gateway to realising sustainability performance via green supply chain management practices: A PLS-ANN approach. Expert Syst. Appl. 2018, 107, 1-14. [CrossRef]

34. Sajjad, A.; Eweje, G. Corporate social responsibility in Pakistan: Current trends and future directions. In Corporate Social Responsibility and Sustainability: Emerging Trends in Developing Economies; Emerald Group Publishing Limited: Bingley, UK, 2014; pp. 163-187.

35. Wittstruck, D.; Teuteberg, F. Understanding the success factors of sustainable supply chain management: Empirical evidence from the electrics and electronics industry. Corp. Soc. Responsib. Environ. Manag. 2012, 19, 141-158. [CrossRef]

36. Hsu, C.-C.; Tan, K.-C.; Mohamad Zailani, S.H. Strategic orientations, sustainable supply chain initiatives, and reverse logistics: Empirical evidence from an emerging market. Int. J. Oper. Prod. Manag. 2016, 36, 86-110. [CrossRef] 
37. Seth, D.; Shrivastava, R.; Shrivastava, S. An empirical investigation of critical success factors and performance measures for green manufacturing in cement industry. J. Manuf. Technol. Manag. 2016, 27, 1076-1101. [CrossRef]

38. Kaynak, H.; Hartley, J.L. A replication and extension of quality management into the supply chain. J. Oper. Manag. 2008, 26, 468-489. [CrossRef]

39. Zhu, Q.; Sarkis, J.; Lai, K.-H. Institutional-based antecedents and performance outcomes of internal and external green supply chain management practices. J. Purch. Supply Manag. 2013, 19, 106-117. [CrossRef]

40. Zhu, Q.; Sarkis, J.; Lai, K.-H. Confirmation of a measurement model for green supply chain management practices implementation. Int. J. Prod. Econ. 2008, 111, 261-273. [CrossRef]

41. Zailani, S.; Jeyaraman, K.; Vengadasan, G.; Premkumar, R. Sustainable supply chain management (SSCM) in Malaysia: A survey. Int. J. Prod. Econ. 2012, 140, 330-340. [CrossRef]

42. Green, K.W., Jr.; Zelbst, P.J.; Meacham, J.; Bhadauria, V.S. Green supply chain management practices: Impact on performance. Supply Chain Manag. Int. J. 2012, 17, 290-305. [CrossRef]

43. Zsidisin, G.A.; Siferd, S.P. Environmental purchasing: A framework for theory development. Eur. J. Purch. Supply Manag. 2001, 7, 61-73. [CrossRef]

44. Eriksson, D.; Svensson, G. Elements affecting social responsibility in supply chains. Supply Chain Manag. Int. J. 2015, 20, 561-566. [CrossRef]

45. Busse, C.; Schleper, M.C.; Niu, M.; Wagner, S.M. Supplier development for sustainability: Contextual barriers in global supply chains. Int. J. Phys. Distrib. Logist. Manag. 2016, 46, 442-468. [CrossRef]

46. Kytle, B.; Ruggie, J.G. Corporate Social Responsibility as Risk Management; Working Paper No. 10; Harvard University Press: Cambridge, MA, USA, 2005.

47. Damanpour, F.; Evan, W.M. Organizational innovation and performance: The problem of "organizational lag". Adm. Sci. Q. 1984, 392-409. [CrossRef]

48. Singh, R.; Mathiassen, L.; Mishra, A. Organizational Path Constitution in Technological Innovation: Evidence from Rural. Telehealth MIS Q. 2015, 39, 643-665. [CrossRef]

49. Coccia, M. Sources of technological innovation: Radical and incremental innovation problem-driven to support competitive advantage of firms. Technol. Anal. Strateg. Manag. 2017, 29, 1048-1061. [CrossRef]

50. Anwar, M. Business model innovation and SMEs performance-Does competitive advantage mediate? Int. J. Innov. Manag. 2018, 22, 1850057. [CrossRef]

51. Barney, J. Firm resources and sustained competitive advantage. J. Manag. 1991, 17, 99-120. [CrossRef]

52. Camisón, C.; Villar-López, A. Organizational innovation as an enabler of technological innovation capabilities and firm performance. J. Bus. Res. 2014, 67, 2891-2902. [CrossRef]

53. Li, Y.; Zhao, Y.; Liu, Y. The relationship between HRM, technology innovation and performance in China. Int. J. Manpow. 2006, 27, 679-697. [CrossRef]

54. Ordanini, A.; Rubera, G. How does the application of an IT service innovation affect firm performance? A theoretical framework and empirical analysis on e-commerce. Inf. Manag. 2010, 47, 60-67. [CrossRef]

55. Miller, D.J.; Fern, M.J.; Cardinal, L.B. The use of knowledge for technological innovation within diversified firms. Acad. Manag. J. 2007, 50, 307-325. [CrossRef]

56. Sirilli, G.; Evangelista, R. Technological innovation in services and manufacturing: Results from Italian surveys. Res. Policy 1998, 27, 881-899. [CrossRef]

57. Ryu, H. The relationship between non-technological innovation and technological innovation on firm performance. Adv. Sci. Technol. Lett. 2016, 135, 27-32.

58. Peteraf, M.A. The cornerstones of competitive advantage: A resource-based view. Strateg. Manag. J. 1993, 14, 179-191. [CrossRef]

59. Wernerfelt, B. A resource-based view of the firm. Strateg. Manag. J. 1984, 5, 171-180. [CrossRef]

60. Alvarez, S.A.; Barney, J.B. Resource-based theory and the entrepreneurial firm. Strateg. Entrep. Creat. 2017, 87-105. [CrossRef]

61. Barney, J.B.; Arikan, A.M. The resource-based view: Origins and implications. Handb. Strateg. Manag. 2001, 124188. [CrossRef]

62. Grant, R.M. The resource-based theory of competitive advantage: Implications for strategy formulation. Calif. Manag. Rev. 1991, 33, 114-135. [CrossRef]

63. Hart, S.L. A natural-resource-based view of the firm. Acad. Manag. Rev. 1995, 20, 986-1014. 
64. Hussain, S.T.; Khan, U.; Malik, K.Z.; Faheem, A. Constraints Faced by Industry in Punjab, Pakistan. Lahore J. Econ. 2012, 17, 135-189. [CrossRef]

65. Krause, D.R.; Handfield, R.B.; Tyler, B.B. The relationships between supplier development, commitment, social capital accumulation and performance improvement. J. Oper. Manag. 2007, 25, 528-545. [CrossRef]

66. Zhu, Q.; Sarkis, J. Relationships between operational practices and performance among early adopters of green supply chain management practices in Chinese manufacturing enterprises. J. Oper. Manag. 2004, 22, 265-289. [CrossRef]

67. Zhu, Q.; Sarkis, J.; Geng, Y. Green supply chain management in China: Pressures, practices and performance. Int. J. Oper. Prod. Manag. 2005, 25, 449-468. [CrossRef]

68. Beske, P.; Seuring, S. Putting sustainability into supply chain management. Supply Chain Manag. Int. J. 2014, 19, 322-331. [CrossRef]

69. Rao, P.; Holt, D. Do green supply chains lead to competitiveness and economic performance? Int. J. Oper. Prod. Manag. 2005, 25, 898-916. [CrossRef]

70. Florida, R. Lean and green: The move to environmentally conscious manufacturing. Calif. Manag. Rev. 1996, 39, 80-105. [CrossRef]

71. Kolk, A. The social responsibility of international business: From ethics and the environment to CSR and sustainable development. J. World Bus. 2016, 51, 23-34. [CrossRef]

72. Marshall, R.S.; Cordano, M.; Silverman, M. Exploring individual and institutional drivers of proactive environmentalism in the US wine industry. Bus. Strategy Environ. 2005, 14, 92-109. [CrossRef]

73. Walker, H.; Jones, N. Sustainable supply chain management across the UK private sector. Supply Chain Manag. Int. J. 2012, 17, 15-28. [CrossRef]

74. Bowen, F.E.; Cousins, P.D.; Lamming, R.C.; Farukt, A.C. The role of supply management capabilities in green supply. Prod. Oper. Manag. 2001, 10, 174-189. [CrossRef]

75. Gimenez, C.; Sierra, V.Sustainable supply chains: Governance mechanisms to greening suppliers. J. Bus. Ethics 2013, 116, 189-203. [CrossRef]

76. Lamming, R.; Hampson, J. The environment as a supply chain management issue. Br. J. Manag. 1996, 7, S45-S62. [CrossRef]

77. Vachon, S.; Klassen, R.D. Extending green practices across the supply chain: The impact of upstream and downstream integration. Int. J. Oper. Prod. Manag. 2006, 26, 795-821. [CrossRef]

78. Pagell, M.; Gobeli, D. How plant managers' experiences and attitudes toward sustainability relate to operational performance. Prod. Oper. Manag. 2009, 18, 278-299. [CrossRef]

79. Baird, P.L.; Geylani, P.C.; Roberts, J.A. Corporate social and financial performance re-examined: Industry effects in a linear mixed model analysis. J. Bus. Ethics 2012, 109, 367-388. [CrossRef]

80. Alexander, G.J.; Buchholz, R.A. Corporate social responsibility and stock market performance. Acad. Manag. J. 1978, 21, 479-486. [CrossRef]

81. Turban, D.B.; Greening, D.W. Corporate social performance and organizational attractiveness to prospective employees. Acad. Manag. J. 1997, 40, 658-672.

82. Orlitzky, M.; Schmidt, F.L.; Rynes, S.L. Corporate social and financial performance: A meta-analysis. Organ. Stud. 2003, 24, 403-441. [CrossRef]

83. Li, F.; Li, T.; Minor, D. CEO power, corporate social responsibility, and firm value: A test of agency theory. Int. J. Manag. Financ. 2016, 12, 611-628. [CrossRef]

84. Wang, J.; Zhang, Y.; Goh, M. Moderating the role of firm size in sustainable performance improvement through sustainable supply chain management. Sustainability 2018, 10, 1654. [CrossRef]

85. Damanpour, F.; Walker, R.M.; Avellaneda, C.N. Combinative effects of innovation types and organizational performance: A longitudinal study of service organizations. J. Manag. Stud. 2009, 46, 650-675. [CrossRef]

86. Galende, J.; de la Fuente, J.M. Internal factors determining a firm's innovative behaviour. Res. Policy 2003, 32, 715-736. [CrossRef]

87. Mol, M.J.; Birkinshaw, J. The sources of management innovation: When firms introduce new management practices. J. Bus. Res. 2009, 62, 1269-1280. [CrossRef]

88. Yang, C.-C.; Marlow, P.B.; Lu, C.-S. Assessing resources, logistics service capabilities, innovation capabilities and the performance of container shipping services in Taiwan. Int. J. Prod. Econ. 2009, 122, 4-20. [CrossRef]

89. Coombs, J.E.; Bierly, P.E. Looking through the kalidescope: Measuring technological capability and performance. Acad. Manag. 2017, B1-B6. [CrossRef] 
90. Coombs, J.E.; Bierly, P.E. Measuring technological capability and performance. Res. Dev. Manag. 2006, 36, 421-438. [CrossRef]

91. Nuria, G.-A.; Mariano, N.-A. Protection and internal transfer of technological competencies: The role of causal ambiguity. Ind. Manag. Data Syst. 2005, 105, 841-856.

92. Teece, D.J.; Pisano, G.; Shuen, A. Dynamic capabilities and strategic management. Strateg. Manag. J. 1997, 18, 509-533. [CrossRef]

93. Ortega, M.J.R. Competitive strategies and firm performance: Technological capabilities' moderating roles. J. Bus. Res. 2010, 63, 1273-1281. [CrossRef]

94. Damanpour, F. An integration of research findings of effects of firm size and market competition on product and process innovations. Br. J. Manag. 2010, 21, 996-1010. [CrossRef]

95. Bessant, J.; Lamming, R.; Noke, H.; Phillips, W. Managing innovation beyond the steady state. Technovation 2005, 25, 1366-1376. [CrossRef]

96. Martinez-Ros, E. Explaining the decisions to carry out product and process innovations: The Spanish case. J. High Technol. Manag. Res. 1999, 10, 223-242. [CrossRef]

97. Porter, M.E. Competitive Advantage: Creating and Sustaining Superior Performance; Free Press: New York, NY, USA, 1985.

98. Sekaran, U.; Bougie, R. Research Methods for Business: A Skill Building Approach; John Wiley \& Sons: Hoboken, NJ, USA, 2016.

99. Carter, C.R.; Kale, R.; Grimm, C.M. Environmental purchasing and firm performance: An empirical investigation. Transp. Res. Part E Logist. Transp. Rev. 2000, 36, 219-228. [CrossRef]

100. Yu, W.; Chavez, R.; Feng, M.; Wiengarten, F. Integrated green supply chain management and operational performance. Supply Chain Manag. Int. J. 2014, 19, 683-696. [CrossRef]

101. Dang, S.; Chu, L. Evaluation framework and verification for sustainable container management as reusable packaging. J. Bus. Res. 2016, 69, 1949-1955. [CrossRef]

102. Zsidisin, G.A.; Hendrick, T.E. Purchasing's involvement in environmental issues: A multi-country perspective. Ind. Manag. Data Syst. 1998, 98, 313-320. [CrossRef]

103. Emmelhainz, M.A.; Adams, R.J. The apparel industry response to "sweatshop" concerns: A review and analysis of codes of conduct. J. Supply Chain Manag. 1999, 35, 51-57. [CrossRef]

104. Krause, D.R.; Scannell, T.V.; Calantone, R.J. A structural analysis of the effectiveness of buying firms' strategies to improve supplier performance. Decis. Sci. 2000, 31, 33-55. [CrossRef]

105. Claudia, N.; Rainer, L.; Florian, K. Integrating sustainability into strategic supplier portfolio selection. Manag. Decis. 2016, 54, 194-221.

106. Tuominen, M.; Hyvönen, S. Organizational innovation capability: A driver for competitive superiority in marketing channels. Int. Rev. Retail Distrib. Consum. Res. 2004, 14, 277-293. [CrossRef]

107. Camisón, C.; Villar López, A. An examination of the relationship between manufacturing flexibility and firm performance: The mediating role of innovation. Int. J. Oper. Prod. Manag. 2010, 30, 853-878. [CrossRef]

108. Daily, B.F.; Bishop, J.W.; Steiner, R. The mediating role of EMS teamwork as it pertains to HR factors and perceived environmental performance. J. Appl. Bus. Res. JABR 2007, 23, 95-109. [CrossRef]

109. Kassinis, G.I.; Soteriou, A.C. Greening the service profit chain: The impact of environmental management practices. Prod. Oper. Manag. 2003, 12, 386-403. [CrossRef]

110. Gimenez, C.; Sierra, V.; Rodon, J. Sustainable operations: Their impact on the triple bottom line. Int. J. Prod. Econ. 2012, 140, 149-159. [CrossRef]

111. Peng, D.X.; Lai, F. Using partial least squares in operations management research: A practical guideline and summary of past research. J. Oper. Manag. 2012, 30,467-480. [CrossRef]

112. Hair, J.F.; Ringle, C.M.; Sarstedt, M. Partial least squares structural equation modeling: Rigorous applications, better results and higher acceptance. Long Range Plan. 2013, 46, 1-12. [CrossRef]

113. Hair, J.F.; Hult, G.T.M.; Ringle, C.; Sarstedt, M. A Primer on Partial Least Squares Structural Equation Modeling (PLS-SEM), 2nd ed.; Sage Publications: Thousand Oaks, CA, USA, 2017.

114. Hair, J.F., Jr.; Sarstedt, M.; Hopkins, L.; Kuppelwieser, V.G. Partial least squares structural equation modeling (PLS-SEM). Eur. Bus. Rev. 2014, 26, 106-121. [CrossRef]

115. Hair, J.F.; Black, W.C.; Babin, B.J.; Anderson, R.E. Multivariate Data Analysis: A Global Perspective, 7th ed.; Prentice-Hall: Upper Saddle River, NJ, USA, 2010. 
116. Henseler, J.; Ringle, C.M.; Sinkovics, R.R. The use of partial least squares path modeling in international marketing. In New Challenges to International Marketing; Emerald Group Publishing Limited: Bingley, UK, 2009.

117. Hair, J.F.; Sarstedt, M.; Ringle, C.M.; Mena, J.A. An assessment of the use of partial least squares structural equation modeling in marketing research. J. Acad. Mark. Sci. 2012, 40, 414-433. [CrossRef]

118. Duarte, P.A.O.; Raposo, M.L.B. A PLS model to study brand preference: An application to the mobile phone market. In Handbook of Partial Least Squares; Springer: Berlin/Heidelberg, Germany, 2010; pp. 449-485.

119. Hulland, J. Use of partial least squares (PLS) in strategic management research: A review of four recent studies. Strateg. Manag. J. 1999, 20, 195-204. [CrossRef]

120. Bijttebier, P.; Delva, D.; Vanoost, S.; Bobbaers, H.; Lauwers, P.; Vertommen, H. Reliability and validity of the Critical Care Family Needs Inventory in a Dutch-speaking Belgian sample. Heart Lung 2000, 29, 278-286. [CrossRef]

121. Sun, W.; Chou, C.-P.; Stacy, A.W.; Ma, H.; Unger, J.; Gallaher, P. SAS and SPSS macros to calculate standardized Cronbach's alpha using the upper bound of the phi coefficient for dichotomous items. Behav. Res. Methods 2007, 39, 71-81. [CrossRef]

122. Bacon, D.R.; Sauer, P.L.; Young, M. Composite reliability in structural equations modeling. Educ. Psychol. Meas. 1995, 55, 394-406. [CrossRef]

123. Bagozzi, R.P.; Yi, Y. On the evaluation of structural equation models. J. Acad. Mark. Sci. 1988, 16, 74-94. [CrossRef]

124. Chin, W.W. The partial least squares approach to structural equation modeling. Mod. Methods Bus. Res. 1998, 295, 295-336.

125. Henseler, J.; Ringle, C.M.; Sarstedt, M. A new criterion for assessing discriminant validity in variance-based structural equation modeling. J. Acad. Mark. Sci. 2015, 43, 115-135. [CrossRef]

126. Henseler, J.; Fassott, G. Testing moderating effects in PLS path models: An illustration of available procedures. In Handbook of Partial Least Squares; Vinzi, V.E., Chin, W.W., Henseler, H., Wang, J., Eds.; Springer: London, UK, 2010; pp. 713-735.

127. Hayes, A.F. Introduction to Mediation, Moderation, and Conditional Process Analysis: A Regression-Based Approach, 1st ed.; Guilford Press: New York, NY, USA, 2013.

128. Dawson, J.F. Moderation in management research: What, why, when, and how. J. Bus. Psychol. 2014, 29, 1-19. [CrossRef]

129. Falk, R.F.; Miller, N.B. A Primer for Soft Modeling; University of Akron Press: Akron, OH, USA, 1992.

130. Cohen, J. Statistical Power Analysis for the Behavioral Sciences; Lawrence Erlbaum Associates: Hillsdale, NJ, USA, 1988.

131. Callaghan, W.; Wilson, B.; Ringle, C.M.; Henseler, J. Exploring causal path directionality for a marketing model using Cohen's path method. In Proceedings of the PLS'07 International Symposium on PLS and Related Methods Causalities Explored by Indirect Observation, Ås, Norway, 5-7 September 2007.

(C) 2020 by the authors. Licensee MDPI, Basel, Switzerland. This article is an open access article distributed under the terms and conditions of the Creative Commons Attribution (CC BY) license (http://creativecommons.org/licenses/by/4.0/). 